\title{
POSTSYNAPTIC EFFECTS OF MAGNESIUM AND CALCIUM AT THE MOUSE NEUROMUSCULAR JUNCTION ${ }^{1}$
}

\author{
JAMES G. MCLARNON AND D. M. J. QUASTEL ${ }^{2}$ \\ Department of Pharmacology, Faculty of Medicine, The University of British Columbia, \\ Vancouver, British Columbia, V6T 1 W5, Canada
}

Received January 3, 1983; Revised March 21, 1983; Accepted March 21, 1983

\begin{abstract}
The effects of elevated magnesium and calcium concentrations on height and time course of miniature endplate currents (MEPCs) at the mouse neuromuscular junction were studied. With both ions, MEPC height was decreased; the rate of decay of MEPCs was reduced in high magnesium and was unchanged in high calcium. Raised $\mathrm{Mg}^{2+}$ or $\mathrm{Ca}^{2+}$ both acted to modify the effects on MEPC time course of procaine, scopolamine, atropine, lidocaine, and quinidine, all of which act to cause biphasic decay of MEPCs in a manner consistent with reversible "plugging" of endplate channels, with rate constants for blocking and unblocking that are sensitive to postsynaptic transmembrane potential. Both the blocking and unblocking rate constants were decreased by increasing divalent ion concentration. No such reduction of rate constants was observed using menthol or pentobarbital, which appear to block channels in a voltage-independent manner.

It is concluded that the divalent ions act to alter the channel environment via interactions with charged groups in or near the endplate channels.
\end{abstract}

Several recent studies have indicated that increased concentrations of divalent ions act to modify the postsynaptic response to acetylcholine at the frog neuromuscular junction. Whereas raised calcium acts to decrease the time constant of decay of miniature endplate currents (MEPCs) (Bregestovski et al., 1979; Magleby and Weinstock, 1980) and the lifetime of single channels (Bregestovski et al., 1979), nickel and strontium increase the time constant of MEPCs and prolong channel duration (Magleby and Weinstock, 1980; Miledi and Parker, 1980). If the ions were simply acting to decrease negative surface charge and thereby alter intramembrane field strength, one would expect a prolongation of the MEPC (and of single channel lifetime) in the same way as occurs with hyperpolarization. Since different divalent ions vary in their effect on the time course of decay of MEPCs in direction and magnitude, it would seem possiblc that any common action in terms of changes in membrane surface charge might be obscured by ion-specific actions on the kinetics of closing of the transmitter-activated channels. Interactions between divalent ions and channel groups have been postulated by Adams et al. (1980) to account

\footnotetext{
'I'his work was supported by grants from the Muscular Dystrophy Association of Canada and the British Columbia Health Care Research Foundation

${ }^{2}$ To whom correspondence should be addressed.
}

for the observation that the permeability and aqueous mobility sequences for a series of divalent ions were considerably different.

In this work we have examined whether an increase in magnesium or calcium ionic concentration at the mouse neuromuscular junction modifies the actions of local anesthetic agents (and agents acting similarly) upon the acetylcholine-activated channel. The postsynaptic action of these agents has been found to be in agreement with the predictions of a sequential model (Steinbach, 1968; Adams, 1976; Ruff, 1977), in which the agent acts to block or plug the open ionic channel. With positively charged local anesthetics, the degree of channel blockade is increased by muscle fiber hyperpolarization and is decreased by depolarization (Kordaš, 1970; Quastel and Linder, 1975; Beam, 1976; Adler et al., 1978); the rate constants for blocking and unblocking are both sensitive to transmembrane potential (Pennefather and Quastel, 1980).

The results of the present experiments indicate that increasing the concentration of either magnesium or calcium ions acts to reduce both the on- and off-rate constants for channel "plugging" by positively charged agents but not for blocking agents that act in the neutral form. The modulation by $\mathrm{Ca}^{2+}$ and $\mathrm{Mg}^{2+}$ of the action of these drugs is consistent with charge screening in the vicinity of the open endplate channel. 


\section{Materials and Methods}

The voltage clamp apparatus and superperfusion method have been described previously (Cooke and Quastel, 1973; Linder and Quastel, 1978). MEPCs were recorded from the mouse diaphragm at room temperature $\left(25^{\circ}\right.$ to $\left.28^{\circ} \mathrm{C}\right)$ and stored digitally on magnetic tape. The recording and averaging procedures used were as given in Linder and Quastel (1978) and Pennefather and Quastel (1981); in the experiments where acetylcholinesterase (AChE) was poisoned with paraoxon, the height and time constant was measured for each MEPC to avoid any distortion in averages produced by diversity in the time course of decay of individual MEPCs. This was not necessary with regard to MEPCs recorded after $\mathrm{AChE}$ poisoning in the presence of drugs which caused biphasic decay of the MEPC.

Solutions. To allow increase of $\mathrm{Ca}^{2+}$ or $\mathrm{Mg}^{2+}$ to $40 \mathrm{~mm}$, standard solutions contained $90 \mathrm{~mm}$ sodium, and sucrose was added where necessary to maintain isosmolarity. Bicarbonate (24 mM) was used as buffer (with solutions bubbled with $5 \% \mathrm{CO}_{2}$ in $\mathrm{O}_{2}$ ) in the raised magnesium concentration studies, and Tris buffer $(5 \mathrm{~mm})$ was used in the high calcium experiments. In one group of experiments, hypertonic solutions were used, with $150 \mathrm{mM}$ sodium. For reasons explained below, in most experiments studies with drugs were done in the presence of $0.4 \mathrm{M}$ ethanol or after poisoning of $\mathrm{AChE}$ with paraoxon ( $4 \mu \mathrm{M}$ concentration added for $5 \mathrm{~min}$ before washing off). In one experiment, the effects of $20 \mathrm{~mm}$ magnesium on the actions of procaine were studied without added ethanol or paraoxon treatment.

Determination of parameters. All of the drugs used gave MEPC time courses with two components in the decay phase. The rate constants for channel "plugging" and "unplugging" can be determined on the assumption of the following sequential model in which drug combines with the open channel form of the receptor (Adams, 1976, 1977; Feltz et al., 1977; Pennefather and Quastel, 1980):

$$
2 \mathrm{ACh}+\mathrm{R}+\mathrm{D} \underset{k-1}{\stackrel{k_{1}}{\rightleftharpoons}} \mathrm{ACh}_{2} \mathrm{R}^{*}+\mathrm{D} \underset{k-2}{\stackrel{k 2[\mathrm{D}]}{\rightleftharpoons}} \mathrm{ACh}_{2} \mathrm{RD}
$$

Here $\mathrm{ACh}_{2} \mathrm{R}^{*}$ represents the biliganded receptor in the open channel form, with which drug (D) combines to form the "plugged" open channel. Note that intermediate steps in the formation of $\mathrm{ACh}_{2} \mathrm{R}^{*}$ from $\mathrm{ACh}$ and $\mathrm{R}$ have been "collapsed" into a single step, and that $k_{-1}$ represents the rate of the normal process of channel closing. This scheme predicts a biphasic decay once channels have been opened; i.e.,

$$
y(t)=\left[\mathrm{ACh}_{2} \mathrm{R}^{*}\right] /\left[\mathrm{ACh}_{2} \mathrm{R}^{*}\right]_{\max }=A \exp (-a t)+B \exp (-b t)
$$

where $y(t)$ is the height of the MEPC at time $t$, relative to the height when all channels were open, with

$$
A=(c-a) /(b-a) ; \quad B=(b-c) /(b-a)
$$

where

$$
\begin{gathered}
c=k_{-2} \\
a, b=\left[S \pm\left(S^{2}-4 \mathrm{R}\right)^{0.5}\right] / 2
\end{gathered}
$$

where,

$$
\begin{gathered}
S=k_{-1}+k_{2}[\mathrm{D}]+k_{-2} \\
\mathrm{R}=k_{-1} k_{-2}
\end{gathered}
$$

Thus, the rate constants can be obtained from $A, B, a$, and $b$ :

$$
\begin{gathered}
k_{-2}=(b-a) A+a \\
k_{-1}=a b / k_{-2}=(A / a+B / b)^{-1} \\
k_{2}[\mathrm{D}]=a+b-k_{-2}-k_{-1}
\end{gathered}
$$

It was found that with this analysis, values for $k_{-1}$ were obtained which were consistently greater than the control values in the absence of drug (by about $15 \%$ for procaine or atropine at $-80 \mathrm{mV}$ ), and, moreover, the normal voltage dependence of $k_{-1}$ (to decrease with hyperpolarization) was abolished or reversed (Pennefather, 1982). These results indicated that one must postulate either that the drugs do indeed alter the behavior of the channel closing step (i.e., the drugs have an effect at a site other than that at which they block or plug the channels) or that the sequential model should be modified to account for the apparent effects on $k_{-1}$. A simple modification to the sequential scheme is the allowance for dissociation from the open-plugged form without passing through the open state; e.g., a cyclic model:

$$
\begin{gathered}
2 \Lambda \mathrm{Ch}+\mathrm{R}+\mathrm{D} \underset{k-1}{\stackrel{k_{1}}{\rightleftharpoons}} \Lambda \mathrm{Ch}_{2} \mathrm{R}^{*}+\mathrm{D} \\
k_{-4} \text { 『 } k_{4} \quad k_{2} \rrbracket k_{-2} \\
2 \mathrm{ACh}+\mathrm{RD} \underset{k_{3}}{\stackrel{k_{3}}{\rightleftharpoons}} \mathrm{ACh}_{2} \mathrm{RD}
\end{gathered}
$$

Provided $k_{-3}$ is negligible, this also predicts a biphasic decay of the form $y(t)=A \exp (-a t)+B \exp (-b t)$. Three of the four rate constants $\left(k_{-1}, k_{2}[\mathrm{D}], k_{-2}\right.$, and $k_{3}$ ) can be obtained from $A, B, a$, and $b$, if the fourth is known. In particular, if one assumes $k_{-1}$ is not altered by the drug, then $k_{-1}$ is known from control experiments, and

$$
\begin{gathered}
c=(b-a) A+a \\
k_{2}[\mathrm{D}]=(a+b)-c-k_{-1} \\
k_{3}=\left(a b-c k_{-1}\right) /\left(k_{2}[\mathrm{D}]\right) \\
k_{-2}=c-k_{3}
\end{gathered}
$$

With this treatment, the values of $k_{2}[\mathrm{D}]$ that are obtained are proportional to the concentration of blocking drug ([D]) while $k_{3}$ and $k_{-2}$ are independent of [D]; i.e., the drug action is explained in terms of channel plugging (Pennefather and Quastel, 1980). It should be noted that, we assume $k_{-3}$ to be negligible since, if it were not, the decay phase would be triphasic rather than biphasic, with a very slow late component. Furthermore, the magnitude of $k_{-4} / k_{4}$ must be small since the peak heights of the MEPCs were little altered by the drugs used. The analysis to find rate constants was independent of MEPC height. To determine $A, B, a$, and $b$, a least squares fitting program was used. Once the slopes and intercepts of the two components were found and the area of the MEPC was determined, the rate constants $k_{2}, k_{-2}$, and $k_{3}$ were calculated. 
It is implicit in these equations, although not obvious, that a decrease of $k_{-1}$ acts to reduce $b$ (the rate constant of the slow component) and increase $B$. Moreover, the initial rate of decay is $k_{-1}+k_{2}[\mathrm{D}]$. As a result, decreasing $k_{-1}$ greatly facilitates estimation of $k_{2}, k_{-2}$, and $k_{3}$. In the present experiments, we have used two methods to reduce $k_{-1}$ : (1) ethanol, which at $0.4 \mathrm{M}$ slows channel closing (i.e., $k_{-1}$ ) by $75 \%$ (Quastel and Linder, 1975) or (2) poisoning of $\mathrm{AChE}$. It can be shown that blockade of $\mathrm{ACh}$ hydrolysis, permitting repeated action of ACh to open channels (Katz and Miledi, 1973), is in effect equivalent to reduction of $k_{-1}$, provided that the $k_{3}$ route is to a form of liganded receptor that dissociates slowly on the time scale of a MEPC.

The values obtained for $k_{2}$ and $k_{-2}$ were generally not very different using the two models above (i.e., within $15 \%$ of one another), and the effects of $\mathrm{Ca}^{2+}$ and $\mathrm{Mg}^{2+}$ on these parameters were independent of which method was used. Only the values obtained by the second model have been tabulated.

\section{Results \\ Preliminary observations}

Effects of raised magnesium and calcium on the height and time course of MEPCs. Raised concentrations of magnesium ( $10 \mathrm{mM}, 20 \mathrm{mM}$, and $40 \mathrm{~mm}$ ) were found to accelerate the decay and decrease the amplitude of MEPCs (Fig. 1, Table I). Increasing the calcium concentration to $20 \mathrm{mM}$ or $40 \mathrm{~mm}$ also decreased MEPC height but had little or no apparent effect on the decay rate (Table 1). No substantial changes in reversal potentials or in the normal voltage sensitivity of the decay rate were observed with raised magnesium or calcium concentrations. In a few experiments, raised $\mathrm{Mg}^{2+}$ was found to have much the same effect on the amplitude of the endplate response to bath-applied carbachol as on MEPC height.

These observations at the mouse neuromuscular junc- tion are similar to previous results from the frog endplate. Lewis (1979) observed a decrease in MEPC height with $10 \mathrm{mM}$ magnesium, and Magleby and Weinstock (1980) and Lewis (1979) found that $10 \mathrm{mM}$ calcium lowered the MEPC amplitude. This decrease of MEPC height with raised calcium was shown to be secondary to reduction of unit channel conductance (" $\gamma$ ") and a small shift in reversal potential in the hyperpolarizing direction (Magleby and Weinstock, 1980); a decrease in $\gamma$ was also noted by Lewis (1979) for both $10 \mathrm{~mm}$ calcium and $10 \mathrm{~mm}$ magnesium. Contrary to an earlier report (Cohen and Van der Kloot, 1978), Magleby and Weinstock (1980) found that MEPC time course was relatively insensitive to $10 \mathrm{mM}$ calcium (see also Cohen and Van der Kloot, 1982). A substantial decrease in single channel lifetime was observed by Bregestovski et al. (1979) with 82 or 160 $\mathrm{mM} \mathrm{Ca}{ }^{2+}$ (in the absence of $\mathrm{Na}^{+}$).

In terms of the scheme given above, the increase of MEPC decay rate by high $\mathrm{Mg}^{2+}$ might be accounted for either by an increase of $k_{-1}$ or by a channel-plugging action of $\mathrm{Mg}^{2+}$. However, with drugs such as procaine, which fit the channel-plugging model, it is found that the initial rate of decay can be expressed as $k_{-1}+k_{2}[\mathrm{D}]$ with only $k_{-1}$ being affected (reduced) by ethanol. 'l'hus, with or without ethanol the absolute (rather than relative) increment in decay rate $\left(k_{2}[\mathrm{D}]\right)$ is the same (Pennefather and Quastel, 1980), and this is also true if AChE poisoning is used instead of ethanol ( $P$. Pennefather and D. M. J. Quastel, manuscript in preparation). The present result-an increase in decay rate by high $\mathrm{Mg}^{2+}$ that is the same percentage-wise after poisoning of $\mathrm{AChE}$, and little if at all altered by $0.4 \mathrm{M}$ ethanol (which itself reduces decay rate $k_{-1}$ by $75 \%$ ) - cannot be reconciled with $\mathrm{Mg}^{2+}$ acting as a channel plugger with a value for $k_{2}[D]$ that is independent of the presence of ethanol, or AChE poisoning. The effect of high $\mathrm{Mg}^{2+}$ on time course under all three conditions is most consistent with an increase of $k_{-1}$.

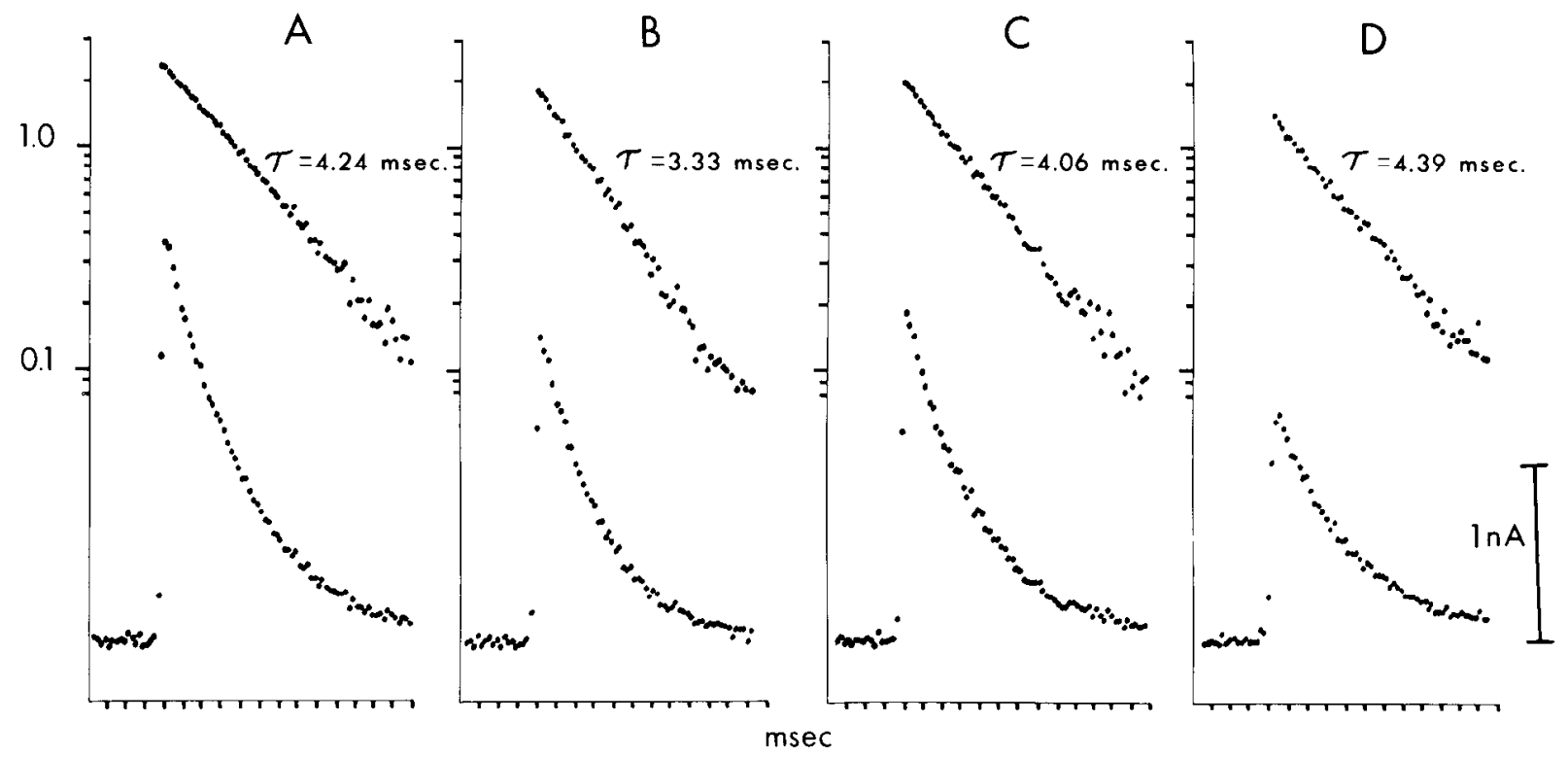

Figure 1. MEPCs plotted linearly (below) and semilog (above) at $-80 \mathrm{mV}$. Solutions were isotonic and contained $0.4 \mathrm{M}$ ethanol. $A$, Control with $1 \mathrm{mM} \mathrm{Mg}^{2+}$ and $2 \mathrm{mM} \mathrm{Ca}{ }^{2+} . B$, Same cell as $A$ with $20 \mathrm{mM} \mathrm{Mg}^{2+}$ and $2 \mathrm{mM} \mathrm{Ca}{ }^{2+}$. $C$, Another control with $1 \mathrm{mM}$ $\mathrm{Mg}^{2+}$ and $2 \mathrm{mM} \mathrm{Ca}{ }^{2+} . D$, Same cell as $C$ with $1 \mathrm{~mm} \mathrm{Mg}{ }^{2+}$ and $20 \mathrm{mM} \mathrm{Ca}^{2+}$. 


\section{TABLE I}

Heights and time constants for MEPCs relative to controls, at $-80 \mathrm{mV}$ for different concentrations of magnesium and calcium

Values are expressed as a ratio to the values obtained in control solution (2 mM Ca, $1 \mathrm{mM} \mathrm{Mg})$ at the same junction + SFM. All solutions contained $90 \mathrm{~mm} \mathrm{Na}$.

\begin{tabular}{|c|c|c|c|}
\hline & \multicolumn{2}{|c|}{ AChE intact } & \multirow{2}{*}{$\begin{array}{c}\text { AChE Poisoned } \\
\text { by Paraoxon }\end{array}$} \\
\hline & 0 Ethanol & $0.4 \mathrm{M}$ Ethanol & \\
\hline \multicolumn{4}{|c|}{ Normalized heights } \\
\hline $20 \mathrm{mM} \mathrm{Mg}$ & $0.78 \pm 0.03(11)$ & $0.71 \pm 0.03(11)$ & $0.79 \pm 0.08$ \\
\hline $40 \mathrm{~mm} \mathrm{Mg}$ & $0.61 \pm 0.02(10)$ & $0.65 \pm 0.04(6)$ & $0.68 \pm 0.09(4)$ \\
\hline $20 \mathrm{mM} \mathrm{Ca}$ & & $0.75 \pm 0.04(6)$ & \\
\hline $40 \mathrm{mM} \mathrm{Ca}$ & & $0.61 \pm 0.03(5)$ & \\
\hline $20 \mathrm{mM} \mathrm{Mg}$ & $0.81 \pm 0.03(11)$ & $0.73 \pm 0.03(11)$ & $0.82 \pm 0.10(3)$ \\
\hline $40 \mathrm{mM} \mathrm{Mg}$ & $0.77 \pm 0.04(10)$ & $0.65 \pm 0.04(6)$ & $0.75 \pm 0.10$ \\
\hline $20 \mathrm{mM} \mathrm{Ca}$ & & $0.99 \pm 0.09(6)$ & \\
\hline $40 \mathrm{mM} \mathrm{Ca}$ & & $1.02 \pm 0.07(5)$ & \\
\hline
\end{tabular}

${ }^{a}$ Numbers in parentheses, number of observations.
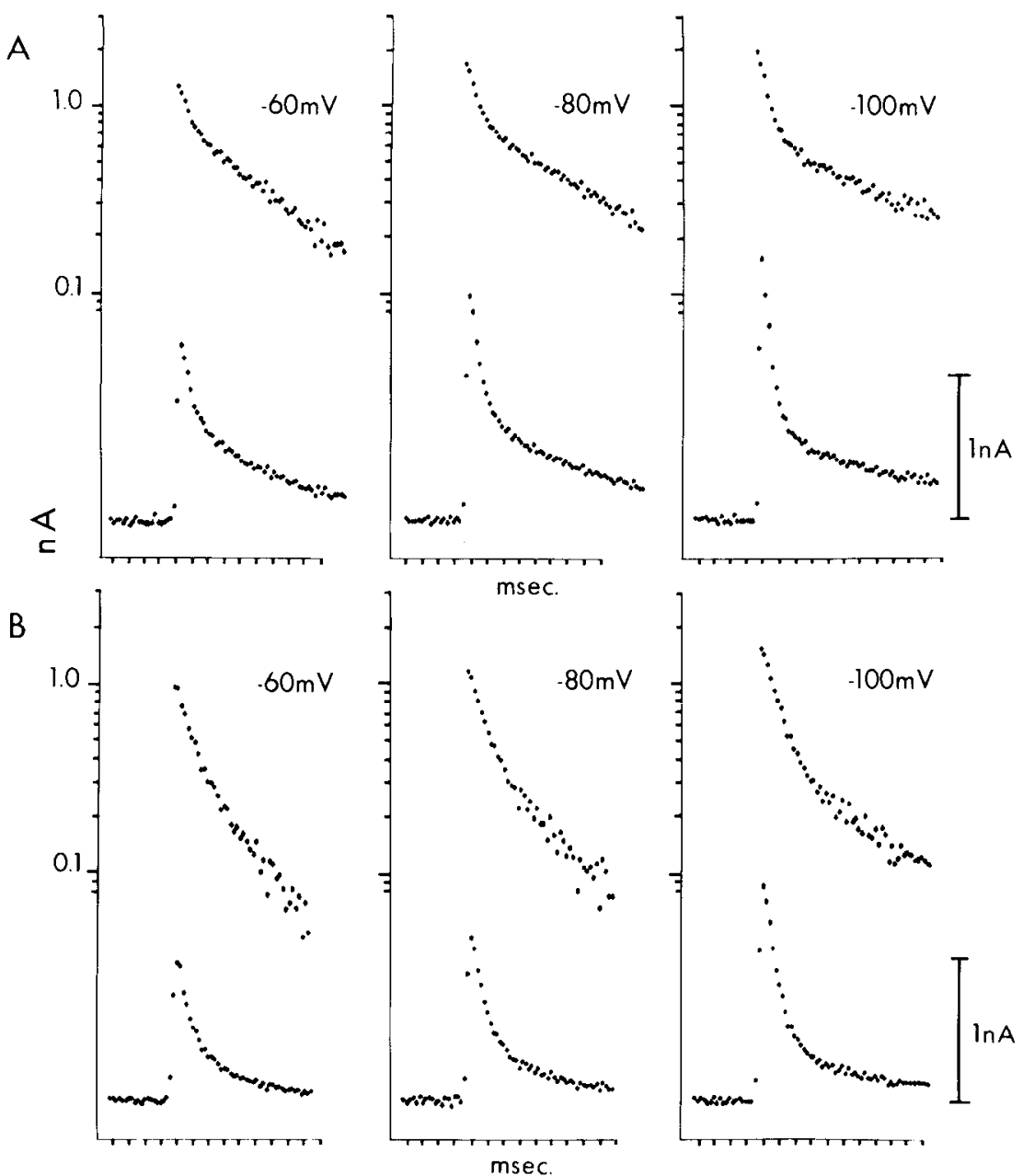

Figure 2. MEPCs (linear and semilog plots as in Fig. 1) in the presence of $25 \mu \mathrm{M}$ procaine at $-60 \mathrm{mV},-80 \mathrm{mV}$, and $-100 \mathrm{mV}$. Solutions also contained $0.4 \mathrm{M}$ ethanol. $A$, Control with $1 \mathrm{mM} \mathrm{Mg}^{2+}$ and $2 \mathrm{mM} \mathrm{Ca}^{2+} . B$, Same cell as $A$ with $40 \mathrm{mM} \mathrm{Mg}^{2+}$ and 2 $\mathrm{mM} \mathrm{Ca}{ }^{2+}$.

Interaction of raised divalent ionic concentrations with local anesthetics. The effects of increased concentrations of magnesium (and, in some experiments, calcium) on the action of the agents procaine, lidocaine, atropine, quinidine, scopolamine, menthol, and pentobarbital were studied. The action of all these drugs on MEPC time course was consistent with blockade or plugging of endplate channels in accord with the sequential model in which the drug combines with the open channel form of the receptor (see "Materials and Methods"). 
Figure 2 shows the effects of $25 \mu \mathrm{M}$ procaine at three different holding potentials with normal $\mathrm{Mg}^{2+}(1 \mathrm{mM})$ and raised $\mathrm{Mg}^{2+}$ (40 mM), and Figure 3 shows the effects of $10 \mu \mathrm{M}$ quinidine at $-80 \mathrm{mV}$ with normal (1 $\mathrm{mM})$ and high $(20 \mathrm{mM}) \mathrm{Mg}^{2+}$. Procaine produces a biphasic decay (both components are voltage sensitive) with a relatively high "split," whereas quinidine yields no obvious slow component but can be identified as a channel blocker because its effect on MEPC decay rate, alone, with ethanol, or after AChE poisoning, accords with the sequential scheme. It is evident that the channel-blocking/ unblocking actions of these drugs were altered in the high magnesium. This alteration involves a decrease in the onward rate constant $k_{2}$ (the initial slope of the fast component of decay is less steep), a decrease in the offrate constant $k_{-2}$ (the inflection point between the fast and slow components is lower), and an increase in the rate constant $k_{-1}$ (the normal action of raised magnesium is to shorten the MEPC decay). Note that because in the sequential scheme the initial rate of fall is essentially $k_{2}[\mathrm{D}]$ plus $k_{-1}$, the fact that both rate constants are individually affected in opposite directions by raised magnesium makes the change in the fast component not always obvious. The decrease in the blocking rate constant with raised magnesium was most apparent with quinidine (Fig. 3) because the unplugging rate constant $\left(k_{-2}\right)$ for this agent is small; the decrease in the rate constant $k_{-2}$ is most clearly evinced with procaine, which has a relatively high $k_{-2}$.

The effects of raised magnesium on the rate constants of the drug actions are shown in Table II. For all of the positively charged agents that were studied, the high magnesium significantly decreased the blocking constant $k_{2}$ with no appreciable difference in the derived values obtained with $0.4 \mathrm{M}$ ethanol or after $\mathrm{AChE}$ poisoning with paraoxon. The channel-unplugging rate constants $\left(k_{-2}\right)$ for the positively charged agents were also consistently diminished when the $\mathrm{Mg}^{2+}$ concentration was in- creased. With the single exception of atropine, these decreases were significant at the $p<0.05$ level. A value of $k_{-2}$ for quinidine action could not be derived since this agent caused little or no tail in the MEPC (Fig. 3).

Raising the calcium concentration to $20 \mathrm{mM}$, in the presence of $0.4 \mathrm{M}$ ethanol, had the same effect as high magnesium on the behavior of the positively charged agents studied (Table II); i.e., both $k_{2}$ and $k_{-2}$ were diminished. Only one drug, procaine, was studied with raised calcium after poisoning of $\mathrm{AChE}$; the results were consistent with the data obtained using ethanol.

The rate constants for the action of pentobarbital and menthol, which evidently "plug" channels with rate constants independent of muscle membrane potential (Adams, 1976; Pennefather and Quastel, 1980; also see Table III), were not affected in the same way as were those of the positively charged agents when the divalent ion concentration was increased. The results in Table II for $V$ $=-80 \mathrm{mV}$ show that, with $0.2 \mathrm{mM}$ pentobarbital, the blocking rate constant $k_{2}$ appeared to be slightly increased in raised $\mathrm{Mg}^{2+}$ and little affected by increased $\mathrm{Ca}^{2+}$. Small but insignificant increases in $k_{2}$ were also noted for raised $\mathrm{Mg}^{2+}$ and pentobarbital at $V=-60 \mathrm{mV}$ and $V=-100 \mathrm{mV}$ (Table III). Raising the $\mathrm{Mg}^{2+}$ concentration also tended to increase the onward rate constant for channel block by $0.2 \mathrm{~mm}$ menthol. For channel unplugging, small but insignificant decreases in $k_{-2}$ were found in raised $\mathrm{Mg}^{2+}$ or $\mathrm{Ca}^{2+}$ with $0.2 \mathrm{mM}$ pentobarbital. Similar small decreases in this rate constant for high $\mathrm{Mg}^{2+}$ and pentobarbital were also noted at holding potentials of $-60 \mathrm{mV}$ and $-100 \mathrm{mV}$ (Table III). Increased $\mathrm{Mg}^{2+}$ did not produce any noticeable change in $k_{-2}$ with menthol as the agent. At one junction (not listed in Table II) studied after poisoning of $\mathrm{AChE}$, the blocking and unblocking rate constants for menthol were also unaltered with increased external magnesium.

The parameter $k_{3}$ in Table II is introduced (see "Materials and Methods") in order to account for the appar-
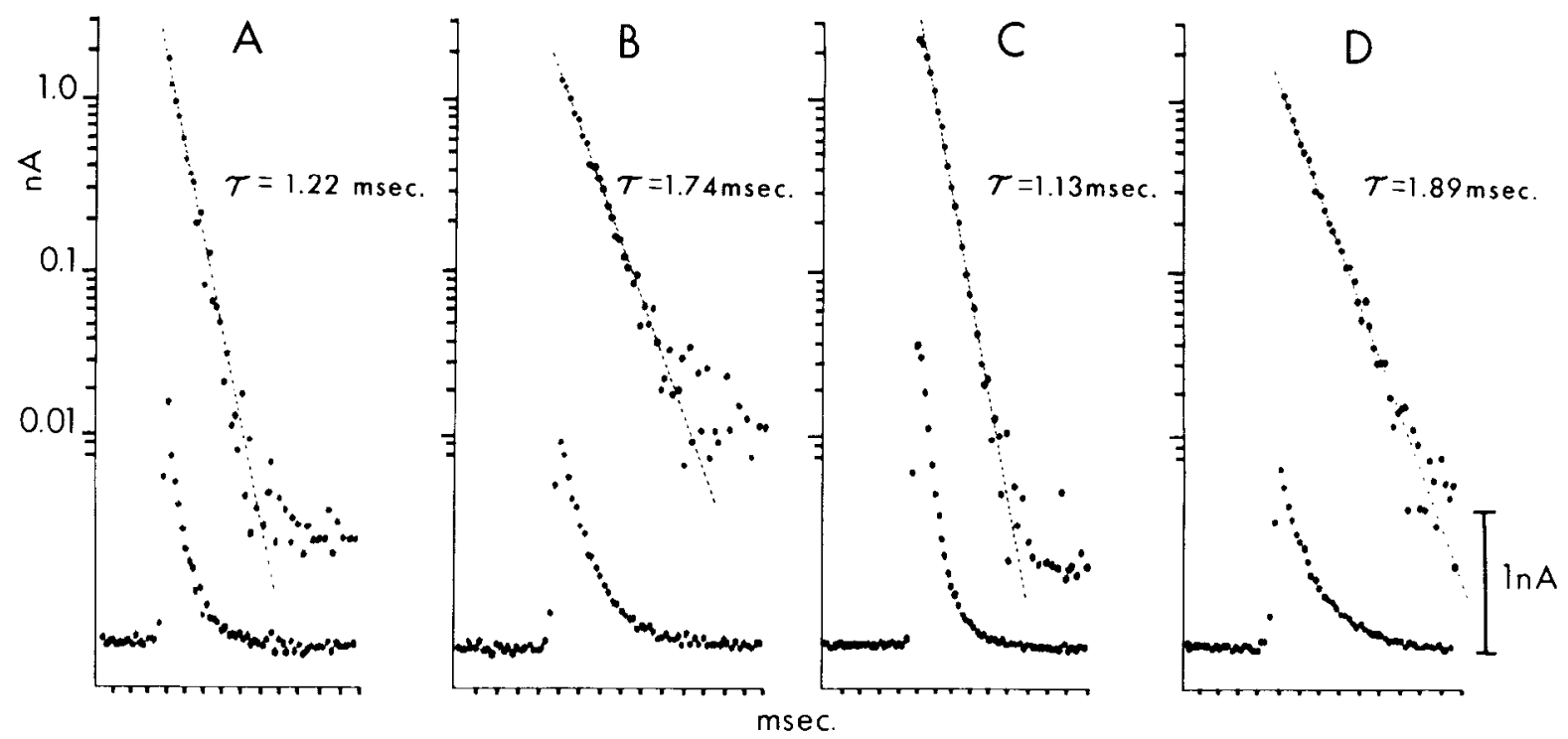

Figure 3. MEPCs (linear and semilog plots as in Fig. 1) in the presence of $10 \mu \mathrm{M}$ quinidine and $0.4 \mathrm{M}$ ethanol. $A$, control with $1 \mathrm{mM} \mathrm{Mg}^{2+}$ and $2 \mathrm{mM} \mathrm{Ca}{ }^{2+} . B$, Same cell as $A$ with $20 \mathrm{mM} \mathrm{Mg}^{2+}$ and $2 \mathrm{mM} \mathrm{Ca}^{2+}$. C, Another control with $1 \mathrm{mM} \mathrm{Mg}^{2+}$ and $2 \mathrm{mM}$ $\mathrm{Ca}^{2+} . D$, Same cell as $C$ with $20 \mathrm{~mm} \mathrm{Mg}^{2+}$ and $2 \mathrm{~mm} \mathrm{Ca}^{2+}$. 
TABLE II

Modification by $\mathrm{Mg}^{2+}$ and $\mathrm{Ca}^{2+}$ of rate constants for channel blockade by various drugs

High $\mathrm{Mg}^{2+}$ concentration was $20 \mathrm{mM}$, except procaine with ethanol and scopolamine with ethanol, where the concentrations were $40 \mathrm{mM}$. Ethanol was used at a concentration of $0.4 \mathrm{M}$. Percentage changes were calculated from paired observations. Holding potentials were $-80 \mathrm{mV}$, except for menthol, where holding potential was $-60 \mathrm{mV}$. All values are $\pm \mathrm{SEM}$.

\begin{tabular}{|c|c|c|c|c|c|c|c|}
\hline \multirow[b]{2}{*}{ Drug } & \multirow{2}{*}{$\begin{array}{l}\text { No. of } \\
\text { Junctions }\end{array}$} & \multicolumn{2}{|c|}{$k_{2}\left(10^{6} \mathrm{M}^{-1} \sec ^{-1}\right)$} & \multicolumn{2}{|c|}{$k_{-2}\left(\mathrm{msec}^{-1}\right)$} & \multicolumn{2}{|c|}{$k_{3}\left(\mathrm{msec}^{-1}\right)$} \\
\hline & & Control & $\begin{array}{l}\text { High } \mathrm{Mg}^{2+} \\
\text { (\% change) }\end{array}$ & Control & $\begin{array}{l}\text { High } \mathrm{Mg}^{2+} \\
(\% \text { change) }\end{array}$ & Control & $\begin{array}{l}\text { High } \mathrm{Mg}^{2+} \\
(\% \text { change })\end{array}$ \\
\hline \multicolumn{8}{|c|}{ Raised $\mathrm{Mg}^{2+}$} \\
\hline \multicolumn{8}{|c|}{ Procaine $(25 \mu \mathrm{M})$} \\
\hline Ethanol & 7 & $28.9 \pm 2.3$ & $-24 \pm 7^{a}$ & $0.59 \pm 0.04$ & $-31 \pm 7^{a}$ & $0.09 \pm 0.05$ & $-22 \pm 44$ \\
\hline $\mathrm{AChE} \mathrm{P}^{b}$ & 2 & $36.7 \pm 5.5$ & $-41 \pm 15^{a}$ & $0.60 \pm 0.06$ & $-28 \pm 10^{a}$ & $0.15 \pm 0.06$ & $0 \pm 33$ \\
\hline \multicolumn{8}{|c|}{ Lidocaine $(25 \mu \mathrm{M})$} \\
\hline Ethanol & 7 & $20.0 \pm 0.8$ & $-46 \pm 4^{a}$ & $0.24 \pm 0.02$ & $-29 \pm 8^{a}$ & $0.03 \pm 0.03$ & $-33 \pm 66$ \\
\hline AChE P & 5 & $16.7 \pm 1.7$ & $-49 \pm 10^{a}$ & $0.27 \pm 0.04$ & $-30 \pm 10^{a}$ & $0.04 \pm 0.03$ & $0 \pm 75$ \\
\hline \multicolumn{8}{|c|}{ Atropine $(25 \mu \mathrm{M})$} \\
\hline Ethanol & 5 & $22.2 \pm 2.0$ & $-32 \pm 9^{a}$ & $0.35 \pm 0.05$ & $-23 \pm 11$ & $0.07 \pm 0.05$ & $+29 \pm 71$ \\
\hline AChE P & 4 & $20.7 \pm 2.5$ & $-24 \pm 9^{a}$ & $0.22 \pm 0.05$ & $-36 \pm 22$ & $0.06 \pm 0.04$ & $+50 \pm 56$ \\
\hline \multicolumn{8}{|c|}{ Quinidine $(10 \mu \mathrm{M})$} \\
\hline Ethanol & 5 & $37.0 \pm 4.6$ & $-43 \pm 10^{a}$ & & & & \\
\hline \multicolumn{8}{|c|}{ Scopolamine $(100 \mu \mathrm{M})$} \\
\hline Ethanol & 7 & $17.7 \pm 5$ & $-33 \pm 5^{a}$ & $1.92 \pm 0.1$ & $54 \pm 10^{a}$ & $0.07 \pm 0.05$ & $0 \pm 26$ \\
\hline \multicolumn{8}{|c|}{ Pentobarbital $(200 \mu \mathrm{M})$} \\
\hline Ethanol & 5 & $2.89 \pm 0.30$ & $+17 \pm 20$ & $0.22 \pm 0.03$ & $-18 \pm 14$ & $0.11 \pm 0.04$ & $-18 \pm 25$ \\
\hline AChE P & 5 & $2.60 \pm 0.26$ & $+8 \pm 10$ & $0.21 \pm 0.06$ & $-15 \pm 25$ & $0.05 \pm 0.03$ & $0 \pm 60$ \\
\hline \multicolumn{8}{|c|}{ Menthol $(200 \mu \mathrm{M})$} \\
\hline Ethanol & 5 & $1.24 \pm 0.15$ & $+18 \pm 20$ & $0.19 \pm 0.02$ & $0 \pm 10$ & $0.13 \pm 0.04$ & $0 \pm 30$ \\
\hline \multirow[b]{2}{*}{ Drug } & & \multicolumn{2}{|c|}{$k_{2}\left(10^{6} \mathrm{M}^{-1} \sec ^{-1}\right)$} & \multicolumn{2}{|c|}{$k_{-2}\left(\mathrm{msec}^{-1}\right)$} & \multicolumn{2}{|c|}{$k_{3}\left(\mathrm{msec}^{-1}\right)$} \\
\hline & $\begin{array}{l}\text { No. of } \\
\text { Junctions }\end{array}$ & Control & $\begin{array}{l}20 \mathrm{mM} \mathrm{Ca}{ }^{2+} \\
(\% \text { change) }\end{array}$ & Control & $\begin{array}{l}20 \mathrm{mM} \mathrm{Ca}^{2+} \\
(\% \text { change })\end{array}$ & Control & $\begin{array}{l}20 \mathrm{mM} \mathrm{Ca}^{2+} \\
(\% \text { change })\end{array}$ \\
\hline \multicolumn{8}{|c|}{ Raised $\mathrm{Ca}^{2+}$} \\
\hline \multicolumn{8}{|c|}{ Procaine $(25 \mu \mathrm{M})$} \\
\hline Ethanol & 4 & $32.9 \pm 5.0$ & $-38 \pm 10^{a}$ & $0.74 \pm 0.07$ & $-34 \pm 10^{a}$ & $0.08 \pm 0.05$ & $+37 \pm 60$ \\
\hline AChE P & 2 & $24.7 \pm 1.2$ & $-17 \pm 12$ & $0.85 \pm 0.05$ & $-39 \pm 6^{a}$ & $0.13 \pm 0.07$ & $+15 \pm 75$ \\
\hline \multicolumn{8}{|c|}{ Lidocaine $(25 \mu \mathrm{M})$} \\
\hline Ethanol & 4 & $23.1 \pm 1.7$ & $-57 \pm 9^{a}$ & $0.25 \pm 0.03$ & $-44 \pm 12^{a}$ & $0.03 \pm 0.03$ & $+33 \pm 100$ \\
\hline \multicolumn{8}{|c|}{ Pentobarbital $(200 \mu \mathrm{M})$} \\
\hline Ethanol & 3 & $3.51 \pm 0.35$ & $-4 \pm 12$ & $0.21 \pm 0.05$ & $-9 \pm 23$ & $0.19 \pm 0.04$ & $-20 \pm 40$ \\
\hline AChE P & 2 & $2.39 \pm 0.27$ & $+11 \pm 20$ & $0.25 \pm 0.04$ & $-8 \pm 12$ & $0.10 \pm 0.06$ & $-5 \pm 30$ \\
\hline
\end{tabular}

${ }^{a}$ Significant difference $(p<0.05)$.

${ }^{b}$ Indicates pretreatment with paraoxon to poison acetylcholinesterase.

TABLE III

Voltage dependence of blocking and unblocking rate constants in raised magnesium solutions with $0.4 \mathrm{M}^{\text {ethanol }}{ }^{a}$

\begin{tabular}{|c|c|c|c|c|c|c|c|c|}
\hline \multirow{2}{*}{ Agent } & \multirow{2}{*}{ Solution } & \multirow{2}{*}{$\begin{array}{c}\text { No. off } \\
\text { Cells }\end{array}$} & \multicolumn{2}{|c|}{$V=-60 \mathrm{mV}$} & \multicolumn{2}{|c|}{$V=-80 \mathrm{mV}$} & \multicolumn{2}{|c|}{$V=-100 \mathrm{mV}$} \\
\hline & & & $k_{2}\left(10^{6} \mathrm{M}^{-1} \mathrm{sec}^{-1}\right)$ & $k_{-2}\left(\mathrm{msec}^{-1}\right)$ & $k_{2}\left(10^{6} \mathrm{M}^{-1} \mathrm{sec}^{-1}\right)$ & $k_{-2}\left(\mathrm{msec}^{-1}\right)$ & $k_{2}\left(10^{6} \mathrm{M}^{-1} \mathrm{sec}^{-1}\right)$ & $k_{-2}\left(\mathrm{msec}^{-1}\right)$ \\
\hline Procaine & Control & 7 & $24.5 \pm 1.4$ & $0.83 \pm 0.03$ & $28.9 \pm 2.3$ & $0.59 \pm 0.04$ & $35.0 \pm 2.5$ & $0.42 \pm 0.03$ \\
\hline$(25 \mu \mathrm{M})$ & $40 \mathrm{mM} \mathrm{Mg}^{2+}$ & 7 & $21.7 \pm 1.5$ & $0.56 \pm 0.05$ & $21.9 \pm 2.2$ & $0.41 \pm 0.04$ & $25.3 \pm 2.7$ & $0.30 \pm 0.03$ \\
\hline Pentobarbital & Control & 5 & $2.60 \pm 0.15$ & $0.22 \pm 0.04$ & $2.89 \pm 0.30$ & $0.22 \pm 0.03$ & $2.50 \pm 0.55$ & $0.18 \pm 0.05$ \\
\hline$(200 \mu \mathrm{M})$ & $20 \mathrm{mM} \mathrm{Mg}^{2+}$ & 5 & $3.23 \pm 0.30$ & $0.20 \pm 0.04$ & $3.37 \pm 0.35$ & $0.18 \pm 0.02$ & $2.60 \pm 0.50$ & $0.16 \pm 0.06$ \\
\hline
\end{tabular}

${ }^{\circ}$ All errors are SEM.

ent increase and reduced voltage sensitivity of $k_{-1}$ caused by some of these drugs (Pennefather and Quastel, 1980). The results (Table II) generally confirm previous measurements (Pennefather and Quastel, 1980) which show, for example, that pentobarbital and menthol have higher $k_{3}$ values than does lidocaine. No systematic effects of raised $\mathrm{Mg}^{2+}$ or $\mathrm{Ca}^{2+}$ on $k_{3}$ were observed for any of the agents studied. Since the determination of $k_{3}$ is made on the assumption that $k_{-1}$ is unchanged by the drug, this result also implies that, if indeed any of these drugs do alter $k_{-1}$, raised $\mathrm{Mg}^{2+}$ or $\mathrm{Ca}^{2+}$ does not modify this action.

In summary, the results indicate that the blocking rate constant $k_{2}$ is diminished in raised magnesium or calcium if the channel-plugging agent carries a net positive charge, but it is essentially unchanged (or slightly increased) if the agent acts in the neutral form. The channel-unplugging rate constant is also diminished with the positively charged agents, with increased divalent ion 
concentration, whereas this rate constant is not significantly altered for the two agents that presumably act as neutral molecules.

Effects of raised magnesium on the voltage dependence of drug action. The effect of raised magnesium ion concentration on the voltage dependence of the drug action was studied for procaine and pentobarbital over a range of transmembrane potentials from $-60 \mathrm{mV}$ to $-100 \mathrm{mV}$ (Table III). The positively charged compounds normally show a voltage sensitivity such that $k_{2}$ is increased with hyperpolarization and $k_{-2}$ is increased with depolarization (see Fig. 2); the magnitude of the rate constants and to some extent their voltage sensitivity vary from agent to agent (Pennefather and Quastel, 1980). The results (Table III) for procaine showed that the addition of high $\mathrm{Mg}^{2+}$ acted to diminish the voltage sensitivity of the onward rate constant $k_{2}$, whereas there was no significant effect on the voltage dependence of the off-rate constant.

The onward and off-rate constants for pentobarbital have been found to be insensitive to membrane potential (Adams, 1976; Pennefather and Quastel, 1980), and this is confirmed in Table III. As noted previously, the addition of divalent ions to solutions containing $0.2 \mathrm{mM}$ pentobarbital did not significantly affect the off (unplugging)-rate constant at $-80 \mathrm{mV}$; this result was also found at $-60 \mathrm{mV}$ and $-100 \mathrm{mV}$. The channel-"plugging" rate constant was slightly increased at $-60 \mathrm{mV}$ (as noted previously for $-80 \mathrm{mV}$ ) and was essentially unchanged at the clamp potential of $-100 \mathrm{mV}$.

Hypertonic solutions. One experiment was done using hypertonic solution containing $0.4 \mathrm{M}$ ethanol with normal sodium concentration and procaine $(25 \mu \mathrm{M})$ at three different holding potentials. The results were not significantly different from those in the isotonic solution with regard to changes in the rate constants induced by the raised magnesium. Both the onward and off-rate constants for procaine action were decreased with $40 \mathrm{~mm}$ magnesium (by $28 \%$ and $21 \%$, respectively, at $-80 \mathrm{mV}$ ) and the normal channel-closing rate $\left(k_{-1}\right)$ was increased by $20 \%$. Moreover, the reduction in the onward rate constant $k_{2}$ was most pronounced at the largest hyperpolarizing potential, indicating that the voltage dependence of the procaine action was reduced, as observed in isotonic solutions.

Studies in the absence of ethanol or paraoxon treatment. A single experiment was carried out using procaine in the absence of ethanol or paraoxon treatment. The measurements, in hypertonic solutions containing $150 \mathrm{mM}$ $\mathrm{Na}^{+}$(where MEPC height is larger than in $90 \mathrm{mM} \mathrm{Na}{ }^{+}$), were made at $18^{\circ} \mathrm{C}$. We have found that low temperature decreases both the blocking and unblocking rate constants and can improve the definition of the time course and thereby aid in the computer fitting for the components. The results showed the blocking and unblocking rate constants to be diminished with $20 \mathrm{mM}$ magnesium by $37 \%$ and $25 \%$, respectively, and the rate constant $k_{-1}$ to be increased by $22 \%$. That is, the effects of $\mathrm{Mg}^{2+}$ on MEPC rate constants were much the same as those observed with added ethanol or AChE poisoned with paraoxon.

\section{Discussion}

At both the frog and the mouse endplates the effects of raised $\mathrm{Mg}^{2+}$ or $\mathrm{Ca}^{2+}$ on the height and time course of MEPCs are consistent with reduction of endplate channel conductance. (Lewis, 1979; Magleby and Weinstock, 1980; Adams et al., 1980), together with alteration of mean channel duration in a manner that varies in direction and magnitude with different divalent cations (Magleby and Weinstock 1980; Miledi and Parker, 1980). The present results show that $\mathrm{Ca}^{2+}$ and $\mathrm{Mg}^{2+}$ also have other effects on endplate channels that become manifest in the presence of positively charged "channel-plugging" agents, such as procaine, lidocaine, quinidine, atropine, and scopolamine. The action of all these drugs is well described by a simple sequential model in which the drug acts "uncompetitively" to attach to the open channel. The "plugged" channels can revert back to an open form with a rate constant characteristic of the drug or can pass on to another state, as discussed under "Materials and Methods" (Pennefather and Quastel, 1980). In terms of this model, the present results indicate actions of divalent ions to modify the rate constants of channel blocking and unblocking by drugs which can be presumed to act in a positively charged form and for which these rate constants are sensitive to transmembrane potential.

With this group of drugs, the unblocking rate constant $k_{-2}$ is decreased by raised $\mathrm{Mg}^{2+}$ or $\mathrm{Ca}^{2+}$, similar to the effect of muscle fiber hyperpolarization. This suggests that with increased divalent ion concentration there is indeed neutralization of fixed negative charges on the membrane in the immediate neighborhood of the open channels, which is sensed by the drug-site(s) binding mechanism as equivalent to membrane hyperpolarization, leading to the slowing of dissociation of the drugchannel complex. Since raised magnesium shortens, rather than lengthens, the time course of decay of MEPCs, it would appear that a "specific" effect of the ions to accelerate the normal channel-closing process counteracts any effect sccondary to change in intramembrane field strength (cf. Cohen and Van der Kloot, 1982). On this basis, the lack of effect of raised $\mathrm{Ca}^{2+}$ on channel lifetime (Magleby and Weinstock, 1980) or on MEPC duration (present results) may reflect a balance between effects to prolong and to shorten decay.

It is notable that the data shown in Table II suggest hydrophobic binding of the plugging agent in or close to the channel, since the unblocking rate constant $\left(k_{-2}\right)$ is least with the most hydrophobic agents, quinidine and lidocaine, and greatest with the least hydrophobic, scopolamine. The distinction is most obvious for the agents scopolamine and atropine, which have very similar structures; the $k_{-2}$ value for the more hydrophobic agent atropine is almost 6 times less than that for scopolamine. A similar dependence of tendency to blockade on hydrophobicity has been noted for organic cations that penetrate the channel, by Adams et al. (1981), who measured single channel conductances and lifetimes at the frog endplate for a series of metal and organic cations.

The onward rate constant for the channel-blocking action of the positive agents (i.e., $k_{2}$ ) was significantly 
decreased by raised $\mathrm{Mg}^{2+}$ or $\mathrm{Ca}^{2+}$. This result is consistent with $(a)$ charge neutralization in the vicinity of the endplate channel leading to a reduced local concentration of the drug or $(b)$ competition of the divalent ions with the drugs for binding sites within the channel. The latter action would imply that the binding site for the positively charged agents is different from that for the neutral agents which showed no decrease in $k_{2}$ in raised $\mathrm{Mg}^{2+}$ or $\mathrm{Ca}^{2+}$. Possibility $b$ would also predict that the action of the divalent ions to reduce $k_{2}$ should itself be sensitive to transmembrane potential; the data for procaine with raised $\mathrm{Mg}^{2+}$ do indeed suggest that this may be the case, since the action of raised magnesium to diminish the onrate constant $k_{2}$ was greatest at $-100 \mathrm{mV}$ and least at $-60 \mathrm{mV}$. If indeed the divalent ions act in this way, one could imagine that they might themselves block the channels: with high onward and off-rate constants the channel would then "flicker" between open and blocked states, giving the apparent low single channel conductance $(\gamma)$ which has been observed (Lewis, 1979; Magleby and Weinstock, 1980). However, such a mechanism also predicts a prolongation of mean apparent channel duration; further modification of the model would be required, to explain why high magnesium causes a faster than normal decay rate of the MEPC with no change in the sensitivity to transmembrane potential of $k_{-1}$ or of MEPC height. The absence of voltage sensitivity of the modification by raised $\mathrm{Mg}^{2+}$ of the $k_{-2}$ for procaine suggests that the sites involved in modification of $k_{-2}$ may be distinct from those involved in altering $k_{2}$.

In summary, the effects of raised $\mathrm{Mg}^{2+}$ and $\mathrm{Ca}^{2+}$ on MEPCs suggest that divalent ions interact with the nicotinic ACh receptor-ionophore system in several distinct ways and presumably at a number of distinct sites. One particular action, prolongation of attachment of positively charged "channel-plugging" agents (i.e., reduction of $k_{-2}$ ), is in the direction expected for neutralization of surface charge on the postsynaptic membrane leading to a change in intramembrane field strength that is sensed by the binding sites for these agents in the same way as membrane hyperpolarization. In addition, $\mathrm{Mg}^{2+}$ and $\mathrm{Ca}^{2+}$ act to impede access of such drugs to their binding sites and have "specific" actions on the lifetime of endplate channels and on channel conductance.

\section{References}

Adams, D. J., T. M. Dwyer, and B. Hille (1980) The permeability of endplate channels to monovalent and divalent metal cations. J. Gen. Physiol. 75: 493-510.

Adams, D. J., W. Nonner, T. M. Dwyer, and B. Hille (1981) Block of endplate channels by permeant cations in frog skeletal muscle. J. Gen. Physiol. 78: 593-615.

Adams, P. R. (1976) Drug blockade of open endplate channels. J. Physiol. (Lond.) 260:531-552.

Adams, P. R. (1977) Voltage jump analysis of procaine action at frog endplates. J. Physiol. (Lond.) 268: 291-318.

Adler, M., E. X. Albuquerque, and F. J. Lebeda (1978) Kinetic analysis of endplate currents altered by atropine and scopolamine. Mol. Pharmacol. 14: 514-529.

Beam, K. G. (1976) A quantitative description of endplate currents in the presence of two lidocaine derivatives. J. Physiol. (Lond.) 258: 301-322.

Bregestovski, P. D., P. Miledi, and I. Parker (1979) Calcium conductance of acetylcholine-induced endplate channels. Nature 279: 638-639.

Cohen, I., and W. Van der Kloot (1978) Effects of calcium and magnesium on the decay of miniature endplate currents. Nature 271: 77-79.

Cohen, I., and W. Van der Kloot (1982) The interaction of extracellular $\mathrm{H}^{+}, \mathrm{Na}^{+}, \mathrm{Ca}^{2+}$ and $\mathrm{Sr}^{2+}$ on the decay of miniature endplate currents. Brain Res. 241: 285-290.

Cooke, J. D., and D. M. J. Quastel (1973) Transmitter release by mammalian motor nerve terminals in response to focal polarization. J. Physiol. (Lond.) 228: 377-405.

Feltz, A., W. A. Large, and A. Trautmann (1977) Analysis of atropine action at the frog neuromuscular junction. J. Physiol. (Lond.) 269: 109-130.

Katz, B., and R. Miledi (1973) The binding of acetylcholine to receptors and its removal from the synaptic cleft. J. Physiol. (Lond.) 231: 549-574.

Kordaś, M. (1970) 'The effect of procaine on neuromuscular transmission. J. Physiol. (Lond.) 209: 689-699.

Lewis, C. A. (1979) Ion concentration dependence of the reversal potential and the single channel conductance of ion channels at the frog neuromuscular junction. J. Physiol. (Lond.) 286: 417-445.

Linder, T. M., and D. M. J. Quastel (1978) A voltage clamp study of the permeability change induced by quanta of transmitter at the mouse endplate. J. Physiol. (Lond.) 281: 535556.

Magleby, K. L., and M. M. Weinstock (1980) Nickel and calcium ions modify the characteristics of the acetylcholine receptor-channel complex at the frog neuromuscular junction. J. Physiol. (Lond.) 299: 203-218.

Miledi, R., and I. Parker (1980) Effects of strontium ions on endplate channel properties. J. Physiol. (Lond.) 306: 567577.

Pennefather, P. (1982) Effects of drugs on miniature endplate currents at the mouse neuromuscular junction. Ph.D. thesis, The University of British Columbia, Vancouver.

Pennefather, P., and D. M. J. Quastel (1980) Actions of anaesthetics on the function of nicotinic acetylcholine receptors. In Molecular Mechanisms of Anesthesia, B. R. Fink, ed., Vol. 2, pp. 45-58, Raven Press, New York.

Pennefather, P., and D. M. J. Quastel (1981) Relation between subsynaptic receptor blockade and response to quantal transmitter at the mouse neuromuscular junction. J. Gen. Physiol. 78: $313-344$.

Quastel, D. M. J., and T. M. Linder (1975) Pre- and postsynaptic actions of central depressants at the mammalian neuromuscular junction. In Molecular Mechanisms of Anesthesia, B. R. Fink, ed., Vol. 1, pp. 157-168, Raven Press, New York.

Ruff, R. L. (1977) A quantitative analysis of local anaesthetic alteration of miniature endplate currents and endplate current fluctuations. J. Physiol. (Lond.) 264: 89-124.

Steinbach, A. B. (1968) A kinetic model for the action of Xylocaine on receptors for acetylcholine. J. Gen. Physiol. 52: 162-180. 